\title{
The Role of Grit In Indonesian Student
}

\author{
Maulana Arif Muhibbin \\ Universitas Airlangga, Surabaya, Indonesia \\ maulana.arif.muhibbin-2019@psikologi.unair.ac.id
}

\author{
Ratna Sari Wulandari \\ Universitas Airlangga, Surabaya, Indonesia \\ ratna.sari-2019@psikologi.unair.ac.id
}

\begin{abstract}
The current systematic review aims to investigate the role of grit in the Indonesian student setting. The search of the literature was conducted on two online databases, ScienceDirect and Google Scholar published between 2016 and 2020. There were seven studies identified using inclusive and exclusive selection criteria in this review. The primary findings demonstrated that grit has a positive influence on career decision-making and academic achievement. Perception of the father's involvement, the meaning of life, growth mindset, school wellbeing, selfcontrol, and life satisfaction are known to have a significant positive correlation with grit. Finally, a positive variable such as self-efficacy can foster students' grit.
\end{abstract}

\section{Keywords: Grit, Student, Indonesia, Education}

\begin{abstract}
Abstrak: Telaah literatur bertujuan untuk menyelidiki peran grit terhadap pelajar di Indonesia. Telaah literatur bersumber dari dua database online, Sciendirect dan Google Scholar yang telah dipublikasi diantara tahun 2016 dan tahun 2020. Terdapat tujuh penelitian yang teridentifikasi memenuhi syarat inclusive dan exclusive. Hasil telaah literatur menunjukkan bahwa grit memiliki pengaruh positif terhadap keputusan pemilihan karir dan prestasi akademik. Persepsi keterlibatan pola asuh ayah, makna hidup, growth mindset, school wellbeing, self control dan kepuasan hidup diketahui memiliki hubungan positif secara signifikan dengan grit. Terakhir, variabel positif yaitu self efficacy diketahui dapat meningkatkan grit yang di miliki oleh siswa Indonesia.
\end{abstract}

Kata kunci: Grit, Siswa, Mahasiswa, Pendidikan, Indonesia 


\section{PENDAHULUAN}

Penelitian yang dilakukan oleh Angela Duckworth dkk di Universitas Pennsylvania (2007) berhasil menemukan sebuah konsep grit, yaitu ketekunan dan kegigihan untuk mencapai tujuan jangka panjang. Grit merupakan kemampuan individu yang dapat membantu individu untuk terus semangat secara berkelanjutan, konsisten dan mampu bangkit setelah menerima kegagalan demi mencapai target-target individu.

Duckworth dkk (2007) dalam konteks pendidikan, mengungkapkan bahwa grit merupakan prediktor yang signifikan untuk mengungkap keberhasilan belajar dan pendidikan siswa. Individu yang memiliki grit yang tinggi akan mampu mencapai Grade Point Averages atau nilai (IPK) lebih tinggi daripada mereka yang kurang memiliki grit. Secara khusus, individu yang memiliki tingkat ketabahan grit (perseverance of effort) yang kuat akan dapat memanfaatkan kemampuannya dalam menguatkan komitment mereka dalam mencapai visi (Credé dkk, 2017). Sehingga mereka tidak terlalu terganggu oleh tujuan jangka pendek dan tidak terlalu takut dengan kegagalan yang mungkin akan terjadi.

Grit terdiri dari dua dimensi utama, yang pertama adalah konsistensi minat (consistency of interest). Aspek ini adalah kemampuan untuk mengatur minat atau perhatian dalam satu tujuan. Interest atau minat dalam konsep ini bukanlah suatu kepuasan yang dituju oleh individu, melainkan suatu makna dari sebuah target yang dijadikan visi oleh individu. Makna yang ada tersebut akan mengikat individu untuk terus berkomitmen mencapai tujuannya (Duckworth dkk, 2007). Minat tidak terpengaruh dalam dimensi waktu jangka pendek, artinya individu akan terus menekuni pekerjaannya karena terjaga oleh minat dalam diri individu (Andrian \& Ilfiandra, 2020). Hal itu dapat disebakan adanya makna dan semangat pribadi untuk mencapai tujuan jangka panjang dalam pekerjaan yang diminatinya (Christopoulou dkk, 2018). Aspek tersebut dalam konteks pendidikan membuat siswa yang memiliki minat yang tinggi dalam pelajaran, akan membuat dirinya tetap menyukai apa yang disampaikan oleh guru serta berkomitmen mengikuti proses belajar mengajar di sekolah hingga selesai.

Dimensi kedua adalah ketekunan usaha (perseverance of effort). Aspek Ini adalah tekad individu untuk mencapai tujuan yang telah ditargetkan meskipun ada rintangan dan tantangan (Duckworth dkk, 2007). Ketekunan menunjukkan adanya kerja keras individu dimana ketekunan berfungsi untuk menangani kesulitan saat menghadapi beberapa kegagalan yang dialami oleh individu. Aspek tersebut dalam ranah pendidikan akan membuat siswa bangkit kembali walaupun mendapat nilai yang buruk. Ketekunan usaha (perseverance of effort) membuat siswa mau untuk belajar kembali meskipun berkali kali gagal. Hal tersebut membuat siswa yang memiliki grit tinggi cenderung memiliki prestasi yang baik pula.

Dua aspek grit tersebut perseverance of effort dan consistency of interest merupakan komponen penting dalam mencapai kesuksesan (Duckworth dkk, 2007). Perseverance atau ketekunan berperan untuk menghargai diri ketika telah melakukan goalyang diinginkan, jika terjadi kegagalan inidividu akan tetap mengapresiasi atas ketekunan usaha yang dilakukan individu. Consistency of interest atau konsistensi minat berperan untuk membuat individu merasa bisa dan bebas mengexplorasi apa yang menjadi goal individu sehingga minatnya tetap terjaga.

Credé, dkk (2017) penelitian yang mereka lakukan berupa kajian meta analisis tentang grit, mereka mengungkapkan bahwa aspek ketekunan dari grit merupakan faktor yang memiliki nilai signifikan tinggi untuk memprediksi performa akademis daripada aspek konsistensi minat grit. 
Penelitian tentang peran grit dalam bidang pendidikan perlu lebih banyak digali, sebab masih ada keragu raguan mengenai dampak dan faktor apa saja yang mempengaruhi grit pada siswa (Almeida, 2016). Hal tersebut sesuai dengan analisa Duckworth dkk (2015), mereka mengakui bahwa pengukuran tingkat grit akan mengarah pada perbedaan antar individu dengan individu lainnya, faktor-faktor kondisional yang belum diketahui bisa saja mempengaruhi tingkat grit individu.

Grit merupakan faktor kepribadian yang menggambarkan perbedaan kemampuan individu dalam mencapai kesuksesan akademik (Christopoulou dkk, 2018). Penelitian yang dilakukan Christopoulou dkk pada tahun (2018), mereka menjelaskan bahwa grit merupakan mekanisme kontra produktif dalam penelitian. Sebab penelitian tentang grit selalu mengaitkan buruknya hasil belajar akibat dari dampak status ekonomi yang rendah. Sementara grit dalam penelitian yang dilakukan Kelly kai lam \& M. Zhou (2018), grit juga diasosiasikan dengan prestasi akademik yang tinggi serta performa belajar yang baik.

Grit merupakan kemampuan non kognitif, sehingga dapat dipengaruhi oleh faktor external seperti halnya kebudayaan (Weisskirch, R. S., 2016). Masyarakat Indonesia memiliki keunikan seperti budaya kolektivistik dan individualistik, asal usul masyarakat yang multikultural, serta variasi model pendidikan seperti pendidikan formal dan pendidikan informal yang diprediksi akan mempengaruhi peran grit terhadap kemampuan belajar dan prestasi siswa Indonesia.

Menelaah peranan pentingnya grit bagi pelajar Indonesia dapat dipahami melalui beberapa survei berikut. Data siswa putus sekolah berdasarkan survei 2016-2019 yang dilakukan Valenta (2019) di Indonesia sebanyak 285.404 anak, survei tersebut juga mengungkapkan bahwa angka putus sekolah paling tinggi adalah siswa menengah kejuruan. Valenta dalam hasil analisanya menjelaskan bahwa salah satu faktor yang membuat siswa putus sekolah adalah masalah minat. Beberapa tahun sebelumnya terdapat penelitian yang dilakukan oleh Imran dkk (2013), mereka mengidentifikasi faktorfaktor yang berhubungan dengan mahasiswa putus kuliah. Mereka mencatat pada salah satu angkatan saja terdapat 234 mahasiswa berstatus drop out, sementara sebanyak 130 mahasiswa mengundurkan diri. Imran dkk (2013) dalam penelitiannya mengungkapkan bahwa nilai IPK sangat berpengaruh terhadap tingginya mahasiswa yang drop out. Nilai IPK yang rendah dapat disebabkan oleh berbagai hal salah satunya adalah minat serta kegigihan mahasiswa dalam proses perkuliahan yang kurang baik (Duckworth dkk, 2007). Data diatas didukung oleh penelitian yang dilakukan oleh Kamsiyati dkk (2016), hasil penelitiannya menjelaskan bahwa faktor dominan yang membuat anak putus sekolah adalah faktor minat.

Grit pada dekade ini menjadi perhatian peneliti untuk mengeplorasi perannya dalam ranah prestasi akademik dan output pendidikan lainnya (Duckworth dkk, 2007). Grit diyakini sebagai prediktor yang lebih unggul daripada IQ siswa dalam menentukan kesuksesan. Hal itu dibuktikan bahwa individu yang memiliki grit tinggi cenderung memiliki levelpendidikan yang tinggi, mudah dalam berkarir dan memiliki nilai IPK yang baik jika dibandingkan dengan individu yang memiliki tingkat grit rendah (Christopoulou dkk, 2018).

Sementara itu penelitian tentang grit dalam ranah pendidikan, kelompok kelas dan dalam proses belajar belajar masih belum banyak dilakukan. Sehingga berdasarkan paparan tersebut perlu untuk menganalisa peran grit pada pelajar di Indonesia.

Oleh karena itu, tujuan dari ulasan ini adalah untuk mendeskripsikan dan 
mengkritisi peran grit dalam konteks pelajar Indonesia, dengan harapan dapat memfasilitasi pemahaman mengenai grit. Oleh sebab itu, penelitian ini fokus ditujukan untuk menjawab dua rumusan masalah sebagaimana berikut: a) Varibel psikologi pendidikan apa yang berasosiasi dengan grit siswa Indonesia? b) Apa saja variabel psikologi prediktor grit pada siswa Indonesia?

\section{METODE}

Rancangan penelitian ini merupakan telaah literatur sistematis yang menyajikan fakta-fakta terkait peran grit terhadap pelajar Indonesia. Database pencarian online dilakukan pada Sciendirect dan Google Scholar yang diterbitkan dari tahun 2016 hingga 2020. Kata kunci yang digunakan untuk mencari makalah yang relevan adalah "grit" dan "Indonesia" dan "grit" dan "indonesia student" dan "grit" dan " siswa" dan "mahasiswa" dan "grit" dan "SMP" dan "grit" dan "SMA" dan "grit". Kriteria inklusi dalam proses pencarian yaitu, 1 . Penelitian yang mengkaji peran grit dalam konteks pendidikan, 2. Fokus subjek pada pelajar Indonesia, 3. Penelitian dilakukan pada rentang tahun 2016-2020, 4. Penelitian menggunakan metode literature review diperbolehkan. Kriteria eksklusi adalah artikel yang tidak memenuhi kriteria inklusi, kecuali makalah yang tidak diterbitkan.

Berdasarkan judul dan abstrak terdapat 11 artikel yang memenuhi syarat. Kemudian proses selanjutnya adalah menelaah metode, isi dan kesimpulan artikel. Kriteria penelitian yang digunakan harus menggunakan metode kuantitatif atau metode literature review dengan subjek penelitian siswa SMP, SMA, atau sederajad dan mahasiswa yang berada di Indonesia.

Pada tahap akhir seleksi artikel, didapati tujuh artikel yang memenuhi syarat inklusif dan eklusif. Dua artikel terpublikasi pada tahun 2018 dan lima artikel terpublikasi pada tahun 2019. Belum ditemukan artikel yang dipublikasikan pada tahun 2016, 2017 dan 2020 yang memenuhi syarat penelitian.

Adapun demografi penelitian adalah sebagai berikut, jumlah sample berkisar paling sedikit 38 orang, hingga yang berjumlah besar 504 pelajar. Lima artikel dengan subjek penelitian mahasiswa perguruan tinggi. Satu artikel dengan subjek penelitian siswa SMP dan satu artikel terakhir menggunakan siswa SMA sebagai subjek penelitiannya.

\section{HASIL DAN PEMBAHASAN}

Terdapat tujuh artikel yang diidentifikasi sesuai dengan kriteria inklusif dan eksklusif. Telaah literatur ini bertujuan untuk merangkum peran grit terhadap pelajar Indonesia. Penelitian yang teridentifikasi tersebut dilakukan pada berbagai daerah yaitu, Lampung, Kota Surabaya, Depok, Purbalingga, Banjar Baru, Kota Bandung, semuanya ada di negara Indonesia. Hasil penelitian tujuh artikel ditampilkan pada tabel berikut.

TabeL 1. Ringkasan penelitian tentang grit pada pelajar Indonesia.

\begin{tabular}{|c|c|c|c|c|c|}
\hline Peneliti \& Judul & Tempat & $\begin{array}{l}\text { Ukuran } \\
\text { Sample (n) }\end{array}$ & Design & $\begin{array}{l}\text { Instrument } \\
\text { pengukuran }\end{array}$ & Temuan \\
\hline $\begin{array}{l}\text { Septania, Khairani } \\
\text { (2019) } \\
\text { Pengaruh Grit dan } \\
\text { Gender dalam } \\
\text { pengambilan } \\
\text { keputusan karir } \\
\text { Mahasiswa }\end{array}$ & $\begin{array}{l}\text { Lampung, } \\
\text { Indonesia }\end{array}$ & 83 Mahasiswa & $\begin{array}{l}\text { Pearson } \\
\text { correlation }\end{array}$ & $\begin{array}{l}\text { Grit scale } \\
\text { (Duckworth.2007) } \\
\text { Decision making scale } \\
\text { (Betz.2004) }\end{array}$ & $\begin{array}{l}\text { Grit dan gender } \\
\text { memberikan } \\
\text { kontribusi efektif } 28 \% \\
(p<0.000) \text { untuk } \\
\text { pengambilan } \\
\text { keputusan karir siswa. }\end{array}$ \\
\hline
\end{tabular}




\begin{tabular}{l}
\hline Peneliti \& Judul \\
\hline Mimbar Oktaviana \\
(2018) \\
The influence of self \\
efficacy towards the \\
grit of \\
multidisciplinary \\
post-graduates \\
students
\end{tabular}

\begin{tabular}{lll} 
Tempat & $\begin{array}{l}\text { Ukuran } \\
\text { Sample (n) }\end{array}$ & Design \\
\hline $\begin{array}{l}\text { Surabaya, } \\
\text { Indonesia }\end{array}$ & 38 Mahasiswa & $\begin{array}{l}\text { T-test, Simple } \\
\text { regression }\end{array}$
\end{tabular}

\section{Instrument \\ pengukuran}

Self efficacy scale

Instrumen dibuat dengan menggunakan teori Bandura dengan besaran, kekuatan dan dimensi umum.

Grit scale

(Duckworth.2007)

Djaling K.W. \&
Purba E.P
(2019)
Efek mediasi makna
hidup pada
hubungan antara
grit dan kepuasan
hidup pada
mahasiswa.

\section{Depok,} Indonesia 505 Mahasiswa

Intervening
analysis.

\section{Grit scale}

(Duckworth.Peterson Matthews, et al. 2007)

Meaning in Life Questionnaire (MLQ) developed by Steger, Frazier, Oishi, and Kaler (2006).

Satisfaction With Life Scale (SWLS) Diener et al. (1985)

Wahidah, Royanto
(2019)
Peran kegigihan
dalam hubungan
growth mindset dan
school well being
siswa sekolah
menengah
Sari,Royanto
(2019)
Nilai prestasi
sebagai moderator
hubungan
kegigihan dengan
prestasi akademik.

\section{Purbalingga,} Indonesia

\section{Siswa SMA} Intervening analysis.

\section{School well-being}

scale (Konu and

Rimpela.2002)

Growth mindset scale

(Dweck .2006)

Grit Scale for Children

and Adult. ( Sturman

and Zappala, Piemme 2017)

Grit Scale for Children

$\begin{array}{lll}\text { Depok, } & 363 \text { Mahasiswa } & \begin{array}{l}\text { Moderate } \\ \text { Regression } \\ \text { Indonesia }\end{array} \\ & \text { Analysis }\end{array}$
and Adult. ( Sturman and Zappala, Piemme 2017)

Academic

Achievement Scale using The Portrait Value Questionaire (PVQ) developed by Schwartz (2003).

\begin{tabular}{|c|c|c|c|c|c|}
\hline $\begin{array}{l}\text { J.A. Justine \& E. } \\
\text { Theresia } \\
\text { (2019) } \\
\text { Grit dan Self- } \\
\text { Control pada } \\
\text { mahasiswa fakultas } \\
\text { kedokteran }\end{array}$ & $\begin{array}{l}\text { Bandung, } \\
\text { Indonesia }\end{array}$ & 114 Mahasiswa & $\begin{array}{l}\text { Corellational } \\
\text { Design }\end{array}$ & $\begin{array}{l}\text { Grit scale } \\
\text { Self control scale } \\
\text { (Duckworth, 2016) }\end{array}$ & $\begin{array}{l}\text { Terdapat hubungan } \\
\text { positif antara grit } \\
\text { dengan self control } \\
\text { mahasiswa } \\
\text { kedokteran }\end{array}$ \\
\hline $\begin{array}{l}\text { Kusumawardhani } \\
\text { dkk } \\
\text { (2018) } \\
\text { Hubungan antara } \\
\text { persepsi } \\
\text { keterlibatan Ayah } \\
\text { dalam pengasuhan } \\
\text { dengan grit pada } \\
\text { peserta didik kelas } \\
\text { Sembilan SMPN } 2 \\
\text { Banjarbaru. }\end{array}$ & $\begin{array}{l}\text { Banjar Baru, } \\
\text { Indonesia }\end{array}$ & 176 Siswa SMP & $\begin{array}{l}\text { Corellational } \\
\text { Design }\end{array}$ & $\begin{array}{l}\text { Father involvement } \\
\text { analysed using } \\
\text { paternal engagement, } \\
\text { and accessibility scale } \\
\text { ( Lamb.2010) } \\
\text { Grit scale (Duckworth. } \\
\text { 2018) }\end{array}$ & $\begin{array}{l}\text { Ada hubungan positif } \\
\text { antara persepsi } \\
\text { keterlibatan ayah } \\
\text { dalam pola asuh } \\
\text { dengan grit pada } \\
\text { siswa }(r=0,234, p= \\
0,05)\end{array}$ \\
\hline
\end{tabular}

\section{Temuan}

Self-efficacy

memberikan kontribusi terhadap variabel grit sebesar $21,8 \%$ dan $78,2 \%$ yang dipengaruhi oleh orang lain.

Terdapat hubungan positif antara grit dan makna hidup. Makna dalam hidup memediasi hubungan antara grit dan kepuasan hidup.
Grit berpengaruh positif pada growth mindset dan grit memediasi hubungan antara school well being dan growth mindset.

\section{Grit memiliki} pengaruh terhadap prestasi akademik Nilai prestasi secara signifikan terbukti sebagai pemoderasi hubungan antara grit dan prestasi

akademik.

Terdapat hubungan positif antara grit pelf control mahasiswa Ada hubungan positif antara persepsi dalam pola asuh dengan grit pada siswa $(r=0,234, p=$ Grit scale (Duckworth. kegigihan dengan
prestasi akademik. 
Penelitian grit di Indonesia lebih banyak dilakukan pada jenjang perguruan tinggi dengan subjek mahasiswa daripada pada jenjang pendidikan menengah seperti SMA atau SMP (Septania \& Khairani, 2019, Oktaviana, 2018, Purba \& Djaling, 2019, Sari \& Royanto, 2019, J.A. Justine \& E. Theresia, 2019).

Hal tersebut dapat dipahami bahwa grit merupakan faktor kognitif yang membutuhkan pengetahuan tentang tujuan jangka panjang, pola pikir akademis, yang mungkin dimiliki oleh mahasiswa di perguruan tinggi (Factors, 2013).

Penelitian yang dilakukan oleh Septania \& Khairani (2019) menguji pengaruh grit dan gender dalam pengambilan keputusan karir mahasiswa. Hasil penelitiannya menunjukkan bahwa grit berhubungan secara signifikan dengan pengambilan keputusan dengan nilai $(r=.519, p=.01)$. Secara simultan grit dan gender berpengaruh secara signifikan degan nilai $(r=.28, p=.01)$. Berdasarkan hal tersebut dapat diartikan bahwa grit dan gender memiliki sumbangan efektif terhadap pengambilan keputusan karir sebesar $28 \%$ sementara sisanya $72 \%$ dipengaruhi oleh faktor lain. Berdasarkan nilai ( $r=.519, p=.01)$ maka dapat dikatakan bahwa pengaruh gritmahasiswa terhadap pengambilan keputusan karir tidak terlalu tinggi.

Berdasarkan review, grit diartikan sebagai ketekunan dan keinginan besar untuk berhasil mencapai target (Duckworth dkk, 2007). Hal tersebut akan memunculkan daya kerja yang kuat untuk menghadapi kesulitan dalam jangka waktu yang lama. Ketika individu memiliki kegigihan dalam mencapai target, maka proses individu dalam menentukan karir di masa depan akan juga terdampak positif. Individu dengan tingkat grit yang baik akan merencanakan karir dengan terorganisir serta terukur sesuai harapan.

Kusumawardhani dkk (2018) melakukan penelitian tentang Hubungan antara persepsi keterlibatan Ayah dalam pengasuhan dengan grit pada peserta didik kelas Sembilan SMPN 2 Banjarbaru. Hasil analisisnya menunjukkan bahwa variabel persepsi keterlibatan Ayah dalam pengasuhan secara signifikan berkorelasi dengan grit siswa dengan nilai $(r=.235, p$ $=.05$ ).

Ayah memiliki peran penting dalam membentuk konsep harga diri anak dan perasaan kompeten dalam diri anak baik dalam hal akademis dan sosial (Kusumawardhani dkk,2018). Siswa yang memiliki persepsi yang baik tentang ayah dalam tugasnya sebagai orang tua akan memiliki keterampilan komunikasi yang lebih baik, membangun kompetensi diri serta membuat siswa berupaya keras untuk mencapai tujuan.

Dalam penelitian yang dilakukan Kusumawardhani dkk (2018) hasil koefisien determinasi bernilai 0,055 dimana sumbangan efektif variabel persepsi keterlibatan ayah terhadap grit hanya sebesar $5,5 \%$ sementara sisanya sebesar $94,5 \%$ dijelaskan oleh faktor lain. Artinya kedua variabel tersebut memiliki hubungan yang rendah. Hal ini dapat dijelaskan bahwa grit merupakan karakter individu yang berasar dari diri atau faktor internal sehingga faktor luar seperti persepsi keterlibatan ayah tidak banyak berkontribusi terhadap grit.

Temuan selanjutnya penelitian tentang efek mediasi makna hidup pada hubungan antara grit dan kepuasan hidup pada mahasiswa yang dilakukan oleh Purba \& Djaling (2019). Hasilnya grit memiliki korelasi positif signifikan dengan variabel makna hidup dengan skore ( $r=$ $0,43, p<.001)$. Grit juga ditemukan berhubungan positif dan signifikan dengan variabel kepuasan hidup dengan nilai $(r=0.41, p<.001)$. Berdasarkan kedua skor tersebut maka dapat dikatakan bahwa individu yang memiliki tingkat grit yang tinggi maka akan memiliki makna hidup dan kepuasan hidup yang tinggi 
pula. Li,J., Fang dkk, (2018) melakukan penelitian serupa, mereka menguji pengaruh grit terhadap kepuasan hidup dengan dimediatori oleh Self esteem. Hasilnya grit berkorelasi positif dengan kepuasan hidup.

Dalam penelitian Purba \& Djaling (2019) data grit diperoleh dari sampel pencapaian akademik. Hubungan variabel diukur antara grit dan kepuasan hidup, sehingga mahasiswa yang memiliki prestasi yang baik akan cenderung memiliki kepuasan hidup yang baik. Terakhir, makna hidup memediasi sebagian hubungan antara grit dan kepuasan hidup $(c=.58 . S E=09, t(505)=$ $6.65, p<.001$ ). Siswa yang lebih berani akan memiliki makna hidup yang kuat sehingga memicu peningkatan kualitas hidup kemudian membawa kepuasan hidup yang sangat besar.

Model mediasi yang juga dilakukan oleh (Wahidah \& Royanto, 2019) dalam penelitiannya tentang Peran kegigihan dalam hubungan growth mindset dan school well being siswa sekolah menengah. Hasilnya menunjukkan bahwa growth mindset memiliki hubungan positif dan signifikan dengan school wellbeing dengan nilai $(r=0.18 ; p<0.01)$. growth mindset juga terkonfirmasi memiliki hubungan yang positif dan signifikan dengan grit $(r=0.39 ; p<0.01)$. Selanjutnya grit berhubungan positif dan signifikan dengan school wellbeing dengan nilai $(r=4.09 ; p<0.01)$.

Berdasarkan hasil korelasi di atas, dapat diketahui bahwa semakin tinggi tingkat growth mindset siswa maka akan semakin tinggi pula school wellbeing siswa. Semakin tinggi derajat growth mindset siswa makan semakin tinggi pula kegigihan siswa. Kemudian semakin tinggi tingkat kegigihan siswa makan school wellbeing siswa akan ikut meningkat.

Analisa dilanjutkan pada tahap regresi untuk mengetahui apakah grit dapat menjadi mediator antara growth mindset dan school wellbeing.
Terkonfirmasi bahwa grit sebagai mediator diantara kedua variabel tersebut dengan nilai koefisien 0.073. Kemudian setelah uji regresi koefisien growth mindset dan school wellbeing menjadi tidak signifikan, yang artinya hubungan antara growth mindset dan school wellbeing dimediasi oleh grit secara sempurna.

Berdasarkan hal tersebut diketahui bahwa untuk mendorong kesejahteraan sekolah (school wellbeing) dibutuhkan mindset berkembang yang memadai dan grityang baik. Sebab growth mindsetakan membantu siswa untuk percaya terhadap kemampuan diri dan memiliki persepi positif terhadap sekolah. Semenatara grit akan membantu siswa untuk tegar dan fokus pada target belajar di sekolah.

Penelitian tentang grit yang lain di lakukan oleh Sari \& Royanto (2019). Mereka meneliti tentang nilai prestasi sebagai moderator hubungan kegigihan dengan prestasi akademik pada mahasiswa. Pada analisis pertama didapati bahwa grit memiliki pengaruh positif terhadap prestasi akademik dengan nilai $(B=.220, t=8.510, p, 0.05)$. Artinya semakin tinggi grit mahasiswa maka akan semakin tinggi pula prestasi akademik mahasiswa.

Hasil ini didukung oleh penelitian sebelumnya Kelly \& Zhou (2018), mereka melakukan study systematic review dan menemukan bahwa grit memiliki hubungan positif dengan prestasi akademik. Dalam tinjauannya, hubungan kuat antara grit dengan prestasi akademik didapati dalam penelitian Akos \& Kretcmar (2017) dan Muenks, K., Yang, J. S., \& Wigfield, A. (2018). Sementara hubungan lemah antara kedua variabel tersebut ditemukan dalam penelitian Kelly dkk (2014) dan Steinmayr, R., Weidinger, A. F., \& Wigfield, A. (2018).

Selanjutnya mereka menggunakan analisis moderasi, pengaruh grit terhadap prestasi belajar $(b=.220, p=.05)$, terdapat interaksi yang signifikan antara grit dan prestasi akademik melalui nilai prestasi (.034 <.05) Hal ini menunjukkan nilai 
prestasi memoderasi hubungan grit dengan prestasi akademik. Artinya mahasiswa yang memiliki pemaknaan tinggi terhadap nilai prestasi akan menunjukkan grit yang tinggi pula hal tersebut menumbuhkan upaya siswa untuk mencapai prestasi akademik.

J.A. Justine \& E. Theresia (2019) melakukan penelitian correlational design tentang grit dan self control mahasiswa kedokteran. Hasil penelitiannya menunjukkan terdapat hubungan positif antara grit dengan self control mahasiswa dengan nilai ( $r=0,531 ; \alpha \leq 0,01)$. Artinya semakin tinggi tingkat grit yang dimiliki oleh mahasiswa maka akan semakin tinggi pula self control mahasiswa tersebut. Self control merupakan suatu kemampuan atensi, emosi dan perbuatan yang dilakukan oleh individu atau bagaimana individu mengontrol perilakunya dalam menyelesikan target jangka pendeknya. Oleh sebab itu, grit akan dapat melengkapi kemampuan self control mahasiswa dalam hal-hal yang bersifat jangka panjang. Angela Duckworth dan James (2014) juga mengungkapkan bahwa grit dan self control merupakan variabel yang saling berhubungan dan penting untuk mencapai kesukesan. Self control akan membuat individu mampu mengatur perhatian dan fokus sedangkan grit akan membuat individu konsisten dalam meraih target jangka panjang. Hal tersebut saling melengkapi karena ada individu yang mampu mengatur fokus dan perilakunya untuk menahan godaan tapi tidak mampu konsisten untuk terus bergerak mencapai goal jangka panjang.

Penelitian terakhir dalam telaah literatur ini adalah penelitian yang dilakukan (Oktaviana, 2018) tentang pengaruh self efficacy terhadap grit mahasiswa. Hasil analisisnya menunjukkan bahwa self efficacy berpengaruh positif dan signifikan terhadap grit $(r=.215, p=$ .01) Self efficacy berkontribusi pada variabel grit sebesar $21,8 \%(R=.464)$ sementara $78,2 \%$ lainnya dijelaskan oleh faktor yang lain. Hal ini menunjukkan kontribusi self efficacy terhadap grit berada dalam kategori sedang.

Usher, Ellen \& Li, Caihong \& Butz, Amanda \& Rojas, Joanne (2018) melakukan penelitian tentang kegigihan dan self efficacy pada anak anak usia SD dan SMP. Hasil temuannya menjelaskan bahwa grit dan self efficacy merupakan prediktor kemampuan anak di sekolah. Namun dalam ranah untuk meningkatkan prestasi belajar, self efficacylebih dominan berpengaruh, sehingga untuk meningkatkan prestasi belajar guru perlu membidik self efficacy siswa terlebih dahulu daripada grit.

Berdasarkan hal tersebut dapat dipahami bahwa ketika siswa memiliki self efficacy yang tinggi maka siswa akan memiliki sikap kegigihan yang tinggi pula. Self efficacy membantu mahasiswa untuk mengendalikan diri untuk tetap bersemangat, tidak mudah stress dan percaya diri ketika menyelesaikan tugas yang sulit. Hal tersebut membuat grit dalam diri mahasiswa mejadi lebih kuat sehingga tidak mudah menyerah dalam menghadapi resiko kegagalan sehingga mahasiswa memiliki potensi untuk menyelesaikan program kuliah dengan memuaskan.

Secara keseluruhan, penelitian tentang peran grit dalam konteks pelajar Indonesia dinilai cukup. Jika dibandingkan dengan penelitian grit dalam lingkup internasional terdapat perbedaan. Konstruk grit secara umum yang dicetuskan oleh Duckwort dkk, (2007) telah dikembangkan oleh Clark dan Malecky (2019) menjadi Academic grit pada konteks pendidikan.

Academic grit merupakan karakter atau kemampuan individu yang meliputi tekad, ketahanan dalam mengejar tujuan jangka panjang pada bidang pendidikan (Clark \& Malecky, 2019). Alat ukur untuk menilai academic grit adalah academic grit ccale yang dikembangkan oleh Clark dan Malecky (2019). Alat ukur ini lebih sesuai dan spesifik untuk menilai kegigihan 
siswa, sebab Academic Grit Scale sangat signifikan berhubungan dengan konstruk pendidikan seperti academic achievement, school satisfaction, nilai IPK dan life satisafaction daripada general grit yang dikembangkan pendahulunya Duckworth dkk (2007).

Tujuh artikel yang meneliti grit pada pelajar indonesia belum ditemukan ada yang menggunakan konsep academic grit, sehingga perlu ada pembaharuan pada penelitian grit dengan subjek pelajar di Indoneisa.

Dari tujuh artikel dapat diamati bahwa sampel yang diuji bersifat heterogen mulai dari tingkat SMP hingga SMA dan sebagian besar dilakukan pada jenjang perguruan tinggi. Oleh sebab itu penelitian grit pada level SMP dan SMA perlu diekplorasi lebih lanjut. Hal ini dikemukakan oleh Credée dkk (2017) bahwa penelitian grit pada anak-anak dan remaja perlu dilakukan untuk mengetahui sejauh mana kekuatan grit pada tiap tahap tahap perkembangan manusia.

Grit merupakan keterampilan nonkognitif yang belum maksimal di terapkan kepada siswa khususnya siswa SMP dan SMA di Indonesia. Grit siswa yang tergolong rendah tergambarkan berdasarkan banyaknya siswa yang putus sekolah karena kurangnya tekad dan kegigihan yang kuat (nasional.kompas, 2010). Penelitian yang dilakukan oleh Kamsihyati dkk (2016) Tentang kajian faktor-faktor penyebab anak putus sekolah menjelaskan bahwa faktor paling dominan penyebab anak putus sekolah adalah faktor minat.

Faktor minat merupakan salah satu aspek dari grit yaitu consistency of interest. Berdasarkan hal tersebut penelitian mengenai grit pada jenjang siswa menengah di Indonesia perlu dilakukan serta mendapat perhatian lebih dari para peneliti oleh sebab masih belum banyak yang membahas grit dalam konteks tersebut.

Disisi lain penelitian grit di Indonesia hampir bersifat heterogen, yakni subjek penelitian mencakup siswa SMP, SMA dan mahasiswa, namun bukan berarti peran grit di Indonesia sudah jelas dan efektif dalam menjelaskan hasil akademik mahasiswa atau siswa. Konsep validitas grit masih akan berkembang (Christopoulou dkk., 2018) Hal tersebut sangat wajar mengingat grit merupakan ciri kepribadian yang dapat dipengaruhi oleh berbagai jenis variabel, seperti budaya, faktor kontekstual, lingkungan belajar dan lain-lain (Duckworth dkk., 2007).

Berdasarkan semua penjelasan diatas, penelitian ini telah menjawab rumusan masalah yang pertama, yaitu variabel psikologi yang diketahui dapat diasosiasikan dengan grit dalam konteks pendidikan di Indonesia adalah keputusan pemilihan karir, prestasi akademik, persepsi keterlibatan pola asuh ayah, makna hidup, growth mindset, school wellbeing, self control dan kepuasan hidup. Kemudian, penelitian ini juga menjawab rumusan masalah yang kedua, yaitu dalam konteks pendidikan di Indonesia diketahui bahwa self efficacy merupakan prediktor yang dapat meningkatkan variabel grit.

\section{KESIMPULAN}

$$
\text { Ada tujuh studi yang }
$$
menggambarkan urgensi grit dalam lingkungan pendidikan. Hasil telaah literatur menunjukkan bahwa grit memiliki pengaruh positif terhadap keputusan pemilihan karir dan prestasi akademik. Persepsi keterlibatan pola asuh ayah, makna hidup, growth mindset, school wellbeing, self control dan kepuasan hidup diketahui memiliki hubungan positif secara signifikan dengan grit. Terakhir, variabel positif yaitu self efficacy diketahui merupakan prediktor yang dapat meningkatkan kegigihan siswa.

Penelitian telaah literatur ini berusahan memahami faktor antcedents grit dan dampak pengaruh grit dalam lingkup pendidikan terhadap pelajar 
Indonesia. Meskipun penelitian tentang grit pelajar Indonesia yang terpublikasi masih sedikit di temui, dalam penelitian ini kami menelaah tujuh artikel untuk menyediakan informasi yang cukup relevan mengenai tema tentang grit pelajar Indonesia. Berdasarkan hasil tinjauan ketujuh artikel yang ditelaah, peneliti dapat menggaris bawahi dan menyelidiki karakteristik grit pada pelajar untuk mencapai kesuksesan baik akademik dan non akademik.

Ada beberapa batasan dalam penelitian ini. Pertama, penelitian tentang grit membutuhkan banyak literatur tetapi terdapat kriteria ekslusif yang tidak dicantumkan, seperti makalah penelitian yang tidak dipublikasikan, dan disertasi yang tidak dipublikasikan. Sehingga menurut Dixson dkk (2016) penelitian tentang konstruk baru seperti grit perlu dilakukan pada lingkup yang luas guna menghindari sampel bias. Penelitian ini hanya terbatas pada setting Indonesia sedangkan kemungkinan besar penelitian tentang grit dilakukan di negara lain. Subjek penelitian pun mayoritas mahasiswa perguruan tinggi, sehingga hasil penelitian grit jika digenelarisasikan akan rentan terjadi sampel bias. Kedua, penelitian tentang grit lebih banyak dibidang performa kerja dan performa belajar, konteks yang lebih luas seperti etnis, budaya dan bakat minat secara khusus masih belum banyak dilakukan.

\footnotetext{
Selanjutnya diharap ada penelitian yang mengulas grit dengan mengasosiasikan dengan etnis, budaya dan gender. Aspek sociocultural berperan penting terhadap nilai yang dibentuk dalam konsep grit seseorang, sebab setiap individu memiliki tantangannya sendiri, memiliki tingkat ekonomi yang berbeda serta fasilitas layanan yang berbeda pula (N.Shechtman,2013). Menurut Weisskirch, R.S. (2016) etnis minoritas akan memiliki stereotipe dan persepsi berbeda dengan etnis mayoritas sehingga akan berdampak
}

terhadap bagaimana individu tersebut menggapai tujuannya. Perbedaan gaya belajar, belajar tradisional dan pembelajaran online perlu ditelaah bagaimana peran grit di dalamnya. Sifat. karakter kelompok belajar di sekolah dalam proses pembelajaran yang dinamis membuat grit masih sangat relevan untuk dikaji serta dicari hubungan sebab akibat antara grit dengan variabel-variabel psikologi. 


\section{DAFTAR PUSTAKA}

Almeida, D. J. (2016). Understanding Grit in the Context of Higher Education. https://doi.org /10.1007 /978-3-31926829-3_11

Andrian, R., \& Ilfiandra. (2020). Grit World Strategy to Evolve the Academic Grits of Senior High School Students. 399 (Icepp 2019), 198-201. https:// doi.org/ 10.2991/ assehr.k. 200130.113

Akos, P., \& Kretchmar, J. (2017). Investigating grit at a non-cognitive predictor of college success. The Review of Higher Education, 40(2), 163-186. doi: 10.1353/ rhe.2017.0000

Christopoulou, M., Lakioti, A., Pezirkianidis, C., Karakasidou, E., \& Stalikas, A. (2018). The Role of Grit in Education: A Systematic Review. Psychology, 09 (15), 2951-2971. https://doi.org/ 10.4236 /psych.2018.915171

Credé, M., Tynan, M. C., \& Harms, P. D. (2017). Much ado about grit: A metaanalytic synthesis of the grit literature. Journal of Personality and Social Psychology, 113(3), 492-511. https:// doi.org/ 10.1037/ pspp0000102

Duckworth, A. L., Peterson, C., Matthews, M. D., \& Kelly, D. R. (2007). Grit: Perseverance and Passion for LongTerm Goals. Journal of Personality and Social Psychology, 92(6), 10871101. https:// doi.org /10.1037/ 0022-3514.92.6.1087

Duckworth, A.L., \& J.Gross James (2014) Self Control and grit: Related but separable determinants of succes. HHS Publisc Access. Departemen of health and human services.USA.

Duckworth, A. L., \& Yeager, D. S. (2015). Measurement Matters: Assessing Personal Qualities Other than Cognitive Ability for Educational Purposes. Educational Researcher, 44 , 237-251. https:// doi.org $/ 10.3102 / 0013189 \times 15584327$
Muenks, K., Yang, J. S., \& Wigfield, A. (2018). Associations between grit, motivation, and achievement in high school students. Motivation Science, 4(2), 158-176. doi: 10.1037/ mot0000076

Dixson, D. D., Worrell, F. C., OlszewskiKubilius, P., \& Subotnik, R. F. (2016). Beyond Perceived Ability: The Contribution of Psychosocial Factors to Academic Performance. Annals of the New York Academy of Sciences, 1377, 67-77. https:// doi.org/10.1111/nyas.13210

Usher, Ellen \& Li, Caihong \& Butz, Amanda \& Rojas, Joanne. (2018). Perseverant Grit and Self-Efficacy: Are Both Essential for Children's Academic Success?. Journal of Educational Psychology. 111. 10.1037/edu0000324.

Factors, C. (2013). Promoting Grit, Tenacity and Perserverance (Issue November).

F.Imran, B. Susetyo \& A.H. Wigena (2013) Identifikasi faktor-faktor yang berhubungan dengan Mahasiswa Putus Kuliah Di IPB Angkatan 2008 menggunakan analisis survival. Departemen Statistika FMIPA IPB Xplore, 2013, Vol. 2(1) :e1(1-6)

J.A. Justine \& E. Theresia (2019) Grit dan self control pada mahasiswa fakultas kedokteran. Humanitas Vol. 3 No. 2, hal. 141 - 154. p-ISSN 2407-2532, eISSN 549-4325.

Kusumawardhani, I. S., Safitri, J., \& Zwagery, R. V. (2018). Pengasuhan dengan grit pada peserta didik kelas sembilan smpn 1 banjarbaru The Relationship between Perception of Fathers Involvement in Parenting with Grit on 9 th Grade. Jurnal Kognisia, 1(2), 70-76. https:// doi.org/ 10.20527 /jk.v1i2.1550

Kelly N. Clark, Christine K. Malecki, (2019) Academic Grit Scale: Psychometric properties and associations with achievement and life satisfaction, Journal of School Psychology, 
Volume 72 Pages 49-66, ISSN 0022-4405, https:// doi.org /10.1016/ j.jsp.2018.12.001.

Kamsihyati Titi, Sutomo, FS. Sakinah (2016). Kajian Faktor-Faktor Penyebab Anak Putus Sekolah di Desa Jangrana Kecamatan Kesugihan Kabupaten Cilacap. ISSN 2250-1321 (online), ISSN 2085-2436 (print) Geo Edukasi Vol. 5, No.1, March 2016 (16 - 21) website:

http://jurnalnasional.ump.ac.id/index. php/GeoEdukasi/index

Kelly kai lam \& M. Zhou (2018)

Relationship between grit and academic Achievement: A systematic review. Hong Kong International Conference on Education.

Li, J., Fang, M., W., Sun, G. and Cheng, Z., (2018) The influence of grit on life satisfaction : Self Esteem as a mediator . Psychologica Belgica, 58 (1), pp. 51- 66. DOI: http:// doi.org/10.5334/pb.400.

N. Shechtman, A. H. Debarger, C. Dornsife, S. Rosier, L. Yarnall. (2013) Promoting grit, tenacity, and perseverance: critical factors for success in the 21 st century. U.S. Departemen of Education Office of Educational Technology.

Oktaviana, M. (2018). The Influence of Self-Efficacy Towards the Grit of Multidisciplinary Post-graduate Students. 212, 352-356. https:// doi.org /10.2991/ icei-18.2018.78

Purba, D. E., \& Djaling, K. W. (2019). Efek Mediasi Makna Hidup Pada Hubungan Antara Grit Dan Kepuasan Hidup Pada Mahasiswa. Jurnal Psikologi Ulayat, 6, 135-149. https:// doi.org /10.24854/ jpu02019-233

Sari, A. A., \& Royanto, L. R. M. (2019). Nilai Prestasi sebagai Moderator Hubungan Kegigihan dengan
Prestasi Akademik. Jurnal Psikologi

Teori Dan Terapan, 9(2), 91.

https://doi.org/10.26740/

jptt.v9n2.p91-100

Septania, S., \& Khairani, K. (2019).

Pengaruh Grit Dan Gender Dalam

Pengambilan Keputusan Karir

Mahasiswa. TAJDID : Jurnal Ilmu

KeislamanDanUshuluddin,22(1),19-

27. https://doi.org/10.15548/

tajdid.v22i1.279

Steinmayr, R., Weidinger, A. F., \& Wigfield, A. (2018). Does students' grit predict their school achievement above and beyond their personality, motivation, and engagement?

Contemporary Educational

Psychology, 53, 106-122. doi:

10.1016/ j.cedpsych.2018.02.004

Valenta Elisa. (2019) Infografik: Anak-anak yang putus sekolah. lokadata.id. https://lokadata.id/artikel/infografikanak-anak-yang-putus-sekolah. Diakses pada tanggal 21 Juli 2021.

Wahidah, F. R., \& Royanto, L. R. M. (2019). Peran Kegigihan Dalam Hubungan Growth Mindset Dan School WellBeing Siswa Sekolah Menengah. Jurnal Psikologi TALENTA, 4(2), 133. https:// doi.org/10.26858/ talenta.v4i2.7618

Weisskirch, R. S. (2016). Grit, Self-Esteem, Learning Strategies and Attitudes and Estimated and Achieved Course Grades among College Students. Current Psychology , 37, 21-27. https:// doi.org / 10.1007/s12144016-9485-4

Kompas. (2010) Ribuan siswa Putus Sekolah. https://edukasi.kompas.com/read/20 10/10/16/15315761/ Ribuan. Siswa. Putus. Sekolah. Diakses pada tanggal 21 Juli 2021. 